\title{
Suitability of some Sudanese mango varieties for jam making
}

\author{
Abdelazim A. M. Nour ${ }^{1}$, Khalid S. M. Khalid ${ }^{1}$ and Gammaa A. M. Osman ${ }^{2}$ \\ ${ }^{1}$ Dept. of Food Science and Technology Faculty of agric. University of Khartoum, Sudan \\ ${ }^{2}$ National Center for Research, Khartoum, Sudan e-mail:gammaaosman@yahoo.com \\ Address: Environment and Natural Resource Research Institute (ENRRI), \\ National Center for Research, P.O. Box 6096. Khartoum 1113. Sudan.
}

\begin{abstract}
The aim of this work was to evaluate the physicochemical characteristics of some Sudanese mango varieties ( Abusamaka, Galb Altour and Magloba), and to study their suitability for jam processing. The storability of mango jam was also studied. The physicochemical properties of the three mango varieties were examined. The jam prepared from different mango extracted pulps were packed into glass jars and stored under room temperature $\left(30^{\circ} \mathrm{C}\right)$ for four months. Optical density, chemical and organoleptic tests were carried out for the prepared mango jams. In addition, the microbial load of the stored prepared jams was determined by the enumeration of total viable count, yeast and mould concentrations. It was observed that the highest level of extracted pulp was that of Malgoba (75.48\%). The obtained results also revealed that Malgoba variety had higher soluble solids and total sugars ( $17^{\circ}$ Brix and $\left.11.93 \%\right)$ compared to the lowest soluble solid and total sugars of the variety Abusamaka ( $11^{\circ}$ Brix and $10.18 \%$ ), however, the highest level of the reducing sugars $(3.45 \%)$ was estimated in Abusamaka variety compared to the lowest value of GulbAltour variety $(2.96 \%)$. These results also revealed that mango pectin extraction yields vary from 20.20 to $7.3 \mathrm{mg} / \mathrm{g}$ depending on the varieties and extraction conditions used. The sensory evaluation results indicated that GulbAltour variety jam was superior in colour, taste and overall acceptability, while Abusamaka variety jam was superior in flavour. The storability results showed that storage at room temperature up to 4 months, significantly affect acidity, however, all mango varieties jams were found to be free from microorganisms.
\end{abstract}

Keywords: Mango. Pectin, Jam, Sugar, Acidity

\section{INTRODUCTION:}

Mango fruit (Mangifera indica $L$ ) is one of the most popular fruits produced in tropical region of the world (Jasim et al, 2005). About more than 1000 varieties have been identified all over the world (FAO, 2005). The annual world production is estimated to around 20 million tonnes (Berardini et al, 2005). In Sudan, mango is considered as an essential horticultural crop, with about 57 varieties and around 0.4 million tonnes annual production (UNEP, 2005). Abass (2001) reported that there are more than 3 millions trees of Baladi mango varieties, the most grown varieties in Sudan, in Abugibaiha and Rashad areas in Southern Kordofan state. It was also reported that mango varieties cultivated in Sudan that cover the majority mango production area, are classified into three groups: True Indian cultivars, Egyptian seedling cultivars of Indian origin such as Zibda, Alphons, Malgoba and Hindibesinara, and Sudanese seedling cultivars of Indian origin of high quality including Shendi, Taimoor, Nailm, Mabroka, Debsha and the famous sort Abu Samaka (Altoum, 2009).
Mango is one of the most cherished fruits, not only in flavour and taste, but also for its nutritional value (Gamman and Sharington , 1981). Malik et al, (1994) reported that mango is a good source of vitamin $A$ and $\mathrm{C}$ and rich in carbohydrates, minerals potassium, and phosphorus. Mango is mostly consumed as fresh fruit but due to its perishable nature it can not be store for long time, and consequently, substantial quantities of the crop are annually lost. Therefore the feasibility of processing mango fruits in many satisfactory products had been tried such products include mango juice, mango nectar, Squash, and mango concentrates and jam (Hussian et al, 2005)

Jam made form different types of fruits are a popular food items among the local population. It is usually prepared from cooked fruit or vegetable, sugars, citric acid and pectin (Broomfield, 1996). The physicochemical characteristics of fruit or vegetable thereof affect the technological quality of the product as some are more suitable than other for specific characteristics, processing of mango into jam is therefore, is highly justifiable the possibility of 
Am. J. Sci. Ind. Res., 2011, 2(1): 17-23

processing jams from mango fruits by different researchers, Kansci et al, (2003) studied the ripening effect of different varieties of mango on the composition and the suitability for jam processing, they concluded that due to the their higher starch contents, all jams prepared with pre-ripe mangoes were more viscous than ripe mango preparation,. The objective of this paper was to study the physicochemical characteristics of some Sudanese mango varieties (Abusamaka, Galb Altour and Magloba), and to evaluate their suitability for jam processing.

MATERIALS AND METHODS: Three Mango varieties, namely Abusamaka, Galb Altour and Magloba which are commonly cultivated and consumed in Sudan, were chosen in this study. Samples from each variety were purchased from Central Market in capital Khartoum. Only fully ripe and sound fruits sample were selected. These fruits were cleaned and kept refrigerated prior to further treatment and analysis.

Mango pulps were extracted from the three varieties and cooked using pan kettles. Sugars, citric acid, pectin and sodium benzoate were then added during cooking (Broomfield,1996) The prepared jams were packed into glass jars and stored under room temperatures $\left(30^{\circ} \mathrm{C}\right)$

For mango fruits varieties, the pulp extraction percentage, viscosity, colour, $\mathrm{pH}$, total soluble solids, acidity, moisture content, ash content, total sugars and reducing sugars were estimated using the official methods of A.O.A.C (1984). The pectin content was determined according to Dekker and Rhichard (1972). For the prepared jams, colour, optical density, $\mathrm{pH}$, acidity, total sugar and reducing sugars were determined using the official methods of A.O.A.C (1984). The prepared mango jams were coded and evaluated organolypicaly for colour, flavour, taste, consistency and overall acceptability, by a panel of 19 trained judges according to the method of Thekoronye and Nagoddy (1985)

The microbial load of the stored prepared jams was determined by the enumeration of total viable count, yeast and mould concentration, as described by Harrigan and Maccane, (1976).

\section{RESULTS}

Physicochemical properties of mango fruits:Table 1 shows the physicochemical properties of the three mango varieties. It was observed that the Magloba variety was much richer in pulp $(75.49 \%)$ followed by Abusamaka $(73.69 \%)$ and Gulb altour $((72.4 \%)$. For viscosity, the results indicated that Magloba was the most viscous variety (3110 cp) while Abusamaka was the least (2303). In term of Total Soluble Solids (TSS), significant differences $(P \leq 0.05)$ could be observed within the three varieties. Magloba variety contained the highest value (17 Brix), while Abusamaka variety showed the least (13 Brix). The results of $\mathrm{pH}$ measurements and acidity values of the three varieties indicated that the most acidic variety was Abusamaka followed by Gulb altour and Magloba. However, for citric acid the higher value was that of Galb Altour followed by Abusamaka and Magloba.

Regarding moisture, ash, fiber contents, significant variations $(P \leq 0.05)$ were noticed for moisture and fiber contents, while significant difference was observed for ash content between the varieties. The results of moisture, ash and fiber content range between $78.8-82.3 \%, 0.67-1.1 \%$, and $3.4-2.15 \%$ respectively. The observation about total and reducing sugars of the three varieties indicated that, for total sugars, value of Magloba variety (11.9\%) were significantly higher than those of Abusamaka $(10.19 \%)$ and Galb Altour (10.71\%). While for reducing sugars, significant differences were observed between the three varieties. Abusamaka variety contained the highest value $(3.45 \%)$ followed by Magloba (3.14\%), while Galb Altour variety showed the least $(2.96 \%)$.

Table 2 represents the results of total pectin concentrations extracted from the three mango varieties, by different concentrations of hydrochloric acid. These results clearly indicated that mango pectin extraction yields vary from 20.20 to $7.3 \mathrm{mg} / \mathrm{g}$ depending on the varieties and extraction conditions used. The higher extraction yields were observed with Magloba for $05 \mathrm{~N}$ and $1.0 \mathrm{~N}$ concentrations of hydrochloric acid, and the lowest with Galb Altour for the same concentrations of hydrochloric acid 
Table 1: The physicochemical properties of mango fruits

\begin{tabular}{lcccccccccc}
\hline $\begin{array}{l}\text { Mango } \\
\text { varieties }\end{array}$ & $\begin{array}{c}\text { Pulp } \\
(\%)\end{array}$ & $\begin{array}{c}\text { Viscosity } \\
(\mathrm{cp})\end{array}$ & $\begin{array}{c}\text { Total solid } \\
(\text { Brix })\end{array}$ & $\mathrm{pH}$ & $\begin{array}{c}\text { Acidity } \\
(\mathrm{Mg} / 100 \mathrm{~g})\end{array}$ & $\begin{array}{c}\text { Moisture } \\
(\%)\end{array}$ & $\begin{array}{c}\text { Ash } \\
(\%)\end{array}$ & $\begin{array}{c}\text { Fiber } \\
(\%)\end{array}$ & $\begin{array}{c}\text { total; sugar } \\
(\%)\end{array}$ & $\begin{array}{c}\text { Reducing sugar } \\
(\%)\end{array}$ \\
\hline & & & & & & & & & & \\
Abusamaka & $73.69^{\mathrm{b}}$ & $2764^{\mathrm{b}}$ & $13.00^{\mathrm{c}}$ & $4.23^{\mathrm{c}}$ & $0.64^{\mathrm{a}}$ & $78.8^{\mathrm{b}}$ & $0.67^{\mathrm{a}}$ & $0.5 .0^{\mathrm{c}}$ & $10.19^{\mathrm{b}}$ & $3.45^{\mathrm{a}}$ \\
GulbAltour & $72.40^{\mathrm{c}}$ & $2303^{\mathrm{c}}$ & $15.00^{\mathrm{b}}$ & $4.65^{\mathrm{b}}$ & $0.86^{\mathrm{a}}$ & $84.2^{\mathrm{a}}$ & $1.10^{\mathrm{a}}$ & $0.95^{\mathrm{b}}$ & $10.71^{\mathrm{b}}$ & $2.96^{\mathrm{c}}$ \\
Magloba & $75.48^{\mathrm{a}}$ & $3110^{\mathrm{a}}$ & $17.00^{\mathrm{a}}$ & $5.00^{\mathrm{a}}$ & $0.19^{\mathrm{a}}$ & $82.5^{\mathrm{a}}$ & $0.90^{\mathrm{a}}$ & $2.15^{\mathrm{a}}$ & $11.95^{\mathrm{a}}$ & $3.14^{\mathrm{b}}$ \\
\hline
\end{tabular}

Means in the same column with different letter (s) are significantly different $(P \leq 0.05)$ according to Least Significant Test (LSD)

Table 2: Pectin content of mango fruits extracted at different acid concentrations

\begin{tabular}{llll}
\hline $\begin{array}{c}\text { Mango } \\
\text { Varieties }\end{array}$ & $1 \mathrm{~N} \mathrm{HCL}$ & $0.5 \mathrm{HCL}$ & $0.05 \mathrm{HCL}$ \\
\hline & & & \\
Abusamaka & $1.02^{\mathrm{ba}}$ & $0.81^{\mathrm{b}}$ & $0.78^{\mathrm{b}}$ \\
GulbAltour & $0.73^{\mathrm{ca}}$ & $0.73^{\mathrm{ba}}$ & $0.87^{\mathrm{ba}}$ \\
Magloba & $2.01^{\mathrm{a}}$ & $2.02^{\mathrm{a}}$ & $1.86^{\mathrm{ab}}$ \\
\hline
\end{tabular}


Am. J. Sci. Ind. Res., 2011, 2(1): 17-23

Table 3: The physicochemical properties of mango jams

\begin{tabular}{lccccc}
\hline $\begin{array}{l}\text { Mango } \\
\text { varieties }\end{array}$ & $\begin{array}{c}\text { Total solid } \\
(\text { Brix })\end{array}$ & $\begin{array}{c}\text { Acidity } \\
(\mathrm{Mg} / 100 \mathrm{~g})\end{array}$ & $\begin{array}{c}\text { Total; sugar } \\
(\%)\end{array}$ & $\begin{array}{c}\text { Reducing sugar } \\
(\%)\end{array}$ & $\begin{array}{c}\text { Optical } \\
\text { density }\end{array}$ \\
\hline & & & & & \\
Abusamaka & $64.5^{\mathrm{b}}$ & $0.67^{\mathrm{b}}$ & $57.14^{\mathrm{b}}$ & $21.94^{\mathrm{b}}$ & $0.84^{\mathrm{b}}$ \\
GulbAltour & $68.0^{\mathrm{a}}$ & $0.96^{\mathrm{a}}$ & $66.13^{\mathrm{a}}$ & $32.33^{\mathrm{a}}$ & $0.97^{\mathrm{b}}$ \\
Magloba & $66.0^{\mathrm{a}}$ & $0.51^{\mathrm{c}}$ & $68.80^{\mathrm{a}}$ & $33.62^{\mathrm{a}}$ & $1.82^{\mathrm{a}}$ \\
\hline
\end{tabular}

Means in the same column with different letter (s) are significantly different $(P \leq 0.05)$ according to Least Significant Test (LSD).

Table 4: The effect of storage on total solids and acidity of mango jams

\begin{tabular}{lcccccc}
\hline Jam & \multicolumn{3}{c}{ Total solids (\%) } & \multicolumn{3}{c}{ Acidy (Mg/100g) } \\
Source & 0 day & 60 days & 120 days & 0 day & 60 days & 120 days \\
\hline & & & & & & \\
Abusamaka & $64.5^{\mathbf{b}}$ & $65.30^{\mathbf{b}}$ & $65.35^{\mathbf{b}}$ & $0.67^{\mathbf{b}}$ & $0.67^{\mathbf{b}}$ & $0.80^{\mathbf{a b}}$ \\
GulbAltour & $67.8^{\mathbf{a}}$ & $68.05^{\mathbf{a}}$ & $64.55^{\mathbf{b}}$ & $0.96^{\mathbf{a}}$ & $0.96^{\mathbf{a}}$ & $0.99^{\mathbf{a}}$ \\
Magloba & $66.0^{\mathbf{b}}$ & $67.00^{\mathbf{a}}$ & $67.08^{\mathbf{a}}$ & $0.51^{\mathbf{c}}$ & $0.61^{\mathbf{a}}$ & $0.64^{\mathbf{b}}$ \\
\hline
\end{tabular}

Means in the same column with different letter $(s)$ are significantly different $(P \leq 0.05)$ according to Least Significant Test (LSD).

Table 5: The effect of storage on total and reducing sugars of mango jams

\begin{tabular}{lcccccc}
\hline Jam & \multicolumn{3}{c}{ Total sugar (\%) } & \multicolumn{3}{c}{ Reducing sugar (\%) } \\
Source & 0 day & 60 days & 120 days & 0 day & 60 days & 120 days \\
\hline & & & & & & \\
Abusamaka & $57.14^{\mathbf{b}}$ & $56.48^{\mathbf{b}}$ & $55.86^{\mathbf{b}}$ & $21.94^{\mathbf{b}}$ & $22.33^{\mathbf{b}}$ & $24.54^{\mathbf{b}}$ \\
GulbAltour & $66.13^{\mathbf{b}}$ & $64.47^{\mathbf{a b}}$ & $65.30^{\mathbf{a}}$ & $32.33^{\mathbf{a}}$ & $33.67^{\mathbf{a}}$ & $33.63^{\mathbf{a}}$ \\
Magloba & $68.80^{\mathbf{a}}$ & $67.05^{\mathbf{a}}$ & $66.13^{\mathbf{a}}$ & $33.63^{\mathbf{a}}$ & $35.61^{\mathbf{a}}$ & $34.11^{\mathbf{a}}$ \\
\hline
\end{tabular}

Means in the same column with different letter (s) are significantly different $(P \leq 0.05)$ according to Least Significant Test (LSD) 
Physicochemical properties of mango jams: The total soluble solids, $\mathrm{pH}$, acidity, optical density, total sugars and reducing sugars for mango jams prepared from the three varieties (Abusamaka, Galb Altour, Magloba) are presented in Table 3 . The total soluble solids for the prepared jam indicated that the TSS varied significantly $(P \leq 0.05)$, the highest value was that of the jam prepared from Gulb Altour variety (68.0 Brix). Data regarding total and reducing sugars varieties, indicated that Magloba jam contained the maximum amount of total and reducing sugar (68.8 $\%$ and $33.52 \%$ ) followed by Galb Altour., with no significant differences between Magloba and Gluab altour, nevertheless, the value of both total and reducing sugars in all jams, were higher than in fresh fruits

Mean values regarding organoleptic evaluation of the jams prepared from the three mango varieties as given in Table 4 exhibited no significant difference $(0$ $<0.05)$ in the score of all attributes among the three with exception of consistency. However, though Abusamaka was superior in term of colour, and magloba gained the best score in taste, the overall acceptability scores were the same for both varieties. Moreover, these varieties are more acceptable.

Effect of storage on physicochemical properties of jams: As shown in Table 5, significant increase in TSS was observed for the three varieties, after four months of storage. The results regarding acidity of jam prepared from different varieties of mango as described in Table 6 indicated that significant increase in acidity of Abusamaka jam was observed after four months of storage. However, insignificant differences were noticed for both Magloba and GulbAltour jams. Table 6 showed that after four months of storage, slight decrease in total sugar was noticed in the three prepared jams. However the results regarding reducing sugars, as described in Table 7, slight increase was observed for the three prepared jams. However the results regarding reducing sugars, as described in Table 7 , slight increase was observed for the three prepared jams. Besides, with respect to the microbial analysis of jam prepared from the three mango varieties, as shown in Table 8, no detectable yeast and mold during the four months of storage.

\section{DISCUSSION:}

Physicochemical properties of mango fruits: It was observed that the pulp of the three mango varieties were found to be more than the pulp percent range of six mango varieties reported by Growd et al
(1995). However, for viscosity, the high viscosity would be attributed to high fiber content, but most especially to the concentration of pectin (Kanci et al, 2003). In term of, significant differences ( $P \leq 0.05)$ could be observed within the three varieties. Magloba variety contained the highest value (17 Brix), while Abusamaka variety showed the least (13 Brix). The findings of Total Soluble Solids (TSS) of the studied varieties were comparable with data about some Sudanese varieties previously reported by Saeed and Khattab, (1974,) and Mohamed (1995). However, the TSS values of these varieties were found to be higher than that reported by Ormalez et al., (2007) who studied several cultivars of mango and found value of TSS of Tommy variety rang at $13 . .6 \pm 2$ Brix.. However, for citric acid the higher value was that of Galb Altour followed by Abusamaka and Magloba. Sabato et al, (2009) reported that the TSS and acidity of mango fruits usually associated with metabolism and significantly affected by the ripening process, therefore dependant on maturity index of the fruit. The results of moisture of the mango varities were almost the same as obtained by Khan, (1989) who reported that the moisture content of some mango varieties produced in Pakistan range between $77.6-82.2 \%$. However, ash and fiber content were less for the same varieties which range $2.85-3.52$ $\%, 3.4-4.92 \%$ respectively.

The variation in sugar contents between different mango varieteis may be attributed to physiological changes and polysaccharides metabolism during ripening process that contribute to accumulation of sugars (Sabato et al, 2009)

The of total pectin concentrations extracted from the three mango varieties results clearly indicated that mango pectin extraction yields vary depending on the varieties and extraction conditions used.

Physicochemical properties of mango jams: Data regarding total and reducing sugars varieties, indicated that, the value of both total and reducing sugars in all jams, were higher than in fresh fruits, mainly due to addition of sugar as well as thermal process that reduced water content (Khan, 1989). The value of optical density of Malgoba jam was higher significantly than both value of Gulb Altour and Abusamaka.

The organoleptic evaluation results of the jams prepared from the three mango varieties showed no significant difference $(0<0.05)$ in the score of all characteristics among the three with exception of consistency. The jam prepared from Abusamaka 
variety was superior in term of colour, and magloba gained the best score in taste, the overall acceptability scores were the same for both varieties. Moreover, these varieties are more acceptable.

Effect of storage on physicochemical properties of jams: Hussian et al (2005) reported that the TSS of mango squash prepared from some Pakistanis mango varieties, increase significantly after 90 days of storage. The results regarding acidity of jam prepared from different varieties of mango indicated that significant increase in acidity of Abusamaka jam was observed after four months of storage. However, insignificant differences were noticed for both Magloba and GulbAltour jams. Igbal et al, (2001) reported that gradual increase in acidity in jams may be due to degradation of pectic substances and formation of uronic acid. Table 6 showed that after four months of storage, slight decrease in total sugar was noticed in the three prepared jams. Similar results of total sugar of jams were reported by Igbal et al, (2001) who observed decrease in total sugar for some prepared mango jams in Pakistan. However the results regarding reducing sugars, slight increase was observed for the three prepared jams. These findings were almost the same as those obtained by Hussian et al, (2005).Besides, with respect to the microbial analysis of jam prepared from the three mango varieties, no detectable yeast and mold during the four months of storage

Table 6: The effect of storage on microbial load of mango jams

\begin{tabular}{lcccccc}
\hline Jam & \multicolumn{2}{c}{ Total viable count (CFU/G) } & \multicolumn{2}{c}{ Yeast and mould (CFU/G) } \\
Source & 0 day & 60 days & 120 days & 0 day & 60 days & 120 days \\
\hline & & & & & & \\
Abusamaka & 0 & 0 & $12^{\mathbf{b}}$ & nil & nil & nil \\
GulbAltour & $12^{\mathbf{b}}$ & $10^{\mathbf{b}}$ & $5^{\mathbf{c}}$ & nil & nil & nil \\
Magloba & $16^{\mathbf{a}}$ & $0^{\mathbf{a}}$ & $13^{\mathbf{b}}$ & nil & nil & nil \\
\hline
\end{tabular}

Means in the same column with different letter (s) are significantly different $(P \leq 0.05)$ according to Least Significant Test (LSD)

Table 7: Means scores of organoleptic attributes of mango jams

\begin{tabular}{lccccc}
\hline $\begin{array}{l}\text { Jam } \\
\text { Source }\end{array}$ & Colour & Flavour & Consistency & Taste & Over all acceptability \\
\hline & & & & & \\
Abusamaka & $39^{\mathrm{b}}$ & $35^{\mathrm{a}}$ & $55^{\mathrm{a}}$ & $42^{\mathrm{a}}$ & $42^{\mathrm{a}}$ \\
GulbAltour & $29^{\mathrm{a}}$ & $36^{\mathrm{a}}$ & $31^{\mathrm{a}}$ & $37^{\mathrm{a}}$ & $35^{\mathrm{a}}$ \\
Magloba & $36^{\mathrm{a}}$ & $40^{\mathrm{a}}$ & $40^{\mathrm{a}}$ & $42^{\mathrm{a}}$ & $42^{\mathrm{a}}$ \\
\hline
\end{tabular}

Means in the same column with different letter (s) are significantly different $(P \leq 0.05)$ according to Least Significant Test (LSD) 


\section{CONCLUSION}

The results of the present study indicated that the three varieties of mango (Abusamaka, Galb Altour and Magloba) were proved to be of good quality Therefore, it can be concluded that jams can be prepared from the three studied varieties and can safely be stored at room temperature for 4 months.

\section{REFERENCES}

Abass, M. A. 2001. Mango production and the suitable varieties for export, processing and consumption. Technical report, Ministry of Agriculture, Sudan.

Eltoum, S. 2009 Mango in Sudan: marketing and Export. PhD Thesis . Institution of Economic, Uppsala. Sweden.

A.O.A.C. (1984). Official Methods of Analysis 14th Edition, Association of Official Analytical Chemis Washington D.C.

Berardini, N., Knodler, M., Schieber, A., \& Carle, R. (2005). Utilization of mango peels as a source of pectin and polyphenolics. Innovative Food Science and Emerging Technologies, 6, 442-452.

Broomfield, R. W. (1996). Manufacture of preserves, flavourings and dried fruits .In:D. Arthery and P. R. Ashurst (eds). Fruit processing. London: Champan and Hall. Pp. 165-196.

Dekker R. F. H., and Richards, G. N. (1972). Determination of pectic substances in plant material. J. Sci. Food. Agric. 23: 475 - 483 .

FAO (2005). FAO statistical data, Food and Agriculture Organization, Rome, Italy.

Gamman, P. and Sharington, K. B. (1981). The science of Food: An Introduction to Food Science . In:Nutrition and microbiology $2^{\text {nd }}$ ed., International library Press.

Gomez, K. A, and Gomez, A. A, (1984) Statistical procedures for agricultural research, second edition, John and wily Sons, Lnc, New York

Growd I. N. D., Ramanjaneya, K. H. lyre, C. P. A., Suramanyam, M. D. K. and Denesh, M. R. (1995). Physicochemical and processing quality of four new mango hybrids in comparison to new commercial cultivars. J. Fd. Sci. and Tech., 31: 385- 388.

Hussian, I., Sabeen, N. G., Muhammed, R. K., Khan, T.M. and Iftikhar, S. (2005).Varietal suitability and storage stability of mango squash. International journal of Agriculture and Biology, 7:1038-1039.

Harrigan W. I. and Maccane M. E. (1976). laboratory methods in microbiology, Academic press. London and New York pp: 303.

Jasim, A., Ramaswamy, H. S., and Hiremath, N. (2005). The effect of high pressure treatment on rheological characteristics and colour of mango pulp. International Journal of Food Science and Technology, 40, 885895.

Igbal, S. A., Yasmin. S. Wadud and Shah, W. H. (2001). Production, storage, packing Food Sci., 11:33-36.

Kansci, G . Benoit B. K. , and Mbome, I. L. (2003). Effect of ripening on the composition and the suitability for jam processing of different varieties of mango (Mangifera indica) African Journal of Biotechnology, 2: 301-306.

Khan, A. (1989). Post-harvest losses during processing and preservation of fruit and vegetable PhD Thesis. Institution of Chemistry, University of Punjab, Lahore.

Malik, M. A., Salam, A. and Saleem, M. (1994). Mango products In:Mango and summer fruits of Pakistan, Saeed, A. (eds) A Brochure of the Hort. Foundation Pakistan, Islamabad.

Mohamed, A. A. (1995). Production of mango fruit bars by dehydration of mang pulp. M Sc. Thesis, University of Khartoum, Sudan.

Ormalez-paz, J. J., Yahia, E. M. and Gardea , B. (2007). Identification and quantification of xanthophylls ester, carotenes and tocopherols in the fruits of six Mexican cultivars, journal of Agriculture and Food Chemistry, 55: 6628-6635.

Sabato, S. F., Da Silva, J. M. and da Cruze, J. N. (2009). Effect of physical, chemical and sensorial of irradiated tommy Atkins mangoes in an international consignment. Food Control, 120:284-288.

Saeed, A.R and Khattab, A. H., (1974). Suitability of mango cultivars for nectars manufacturers. Sudan J. Food Sci. Tech., 6: 24-31.

Thekoronye, N. I., and Nagoddy, P. O. (1985). Integrated food science and technology for tropics. Macmillian Pub. Pp: 180-181.

UNEP (2005). Sudan action plan part 2, Convention on biological diversity (CBD), United Nations Environment Programme, pp $16-17$. 